\title{
SURVEY OF ANDROID APPS FOR AGRICULTURE SECTOR
}

\author{
Hetal Patel and Dharmendra Patel \\ Assistant Professor, Smt. Chandaben Mohanbhai Patel Institute of Computer \\ Applications, CHARUSAT, Changa
}

\begin{abstract}
India is an agriculture based developing country. Information dissemination to the knowledge intensive agriculture sector is upgraded by mobile-enabled information services and rapid growth of mobile telephony. It bridge the gap between the availability of agricultural input and delivery of agricultural outputs and agriculture infrastructure. Mobile computing, cloud computing, machine learning and soft computing are the immerging techniques which are being used in almost all fields of research. Apart from this, they are also useful in our day-to-day activities such as education, medical and agriculture. This paper explores how Android Apps of agricultural services have impacted the farmers in their farming activities.
\end{abstract}

\section{KEYWORDS}

Android Apps, Mobile computing, Machine learning, Cloud computing

\section{INTRODUCTION}

This Agriculture is the primary occupation of the larger part of Indian population. $65-70 \%$ of Indian population is being depends on agriculture for their living. The challenging task for farmers is information management mainly in terms of the amount of data and the complexity of processes in precision farming.

The data regarding farming are available from many sources like printed media, audio and visual aids, newspaper, TV, internet, mobile etc. but the formats and structures of data are dissimilar. So it's very hard for farmer to get the information and to understand the various information which are disseminate from various sources. Sometime many manual steps are required while processing data for transforming data from one format to another.

The progression in the agriculture production straight increases the Indian Economy and viceversa is also true. Mobile apps in the arena of agriculture can be the best option to increase countries'agriculture production. The inventions in technology in agriculture domain are not getting to the farmers; because of either most of them are illiterates or due to unawareness of the location from where they can have information. Hence, utmost of the farmers is being failed in acquisition of the possible production rate [4].

Today farmers are receiving diverse facts or information about faming like seeds, crop selection, crop processes weather, fertilizer, pesticides etc. from various resources which are distributed on 
International Journal of Information Sciences and Techniques (IJIST) Vol.6, No.1/2, March 2016

many different locations according to its origin, its processors, producers or vendors. The data having different format and may have different specific contents can be heterogeneous in their structure and format [1]. Therefore it is required to develop a system from where the required information is available to the farmer directly.

New opportunities are shaped by smart phone technology for farmers. Farmers are capable with a low cost smart phone and the particular software to gain facilities which couldn't available on their hands before. In the days of financial crisis, farming is becoming more and more vigorous and much more important to be completed efficiently during the time period. Several mobile applications have been developed for acquisition of data in the field [1], livestock management [3], AgroMobile [4], Krishiville [5] etc. This paper deals with the analysis of available android based applications which are useful for farmers.

\section{SMART PHONES}

Information and Communication Technologies has seen a powerful role in daily life of farmers. ICT (Information and Communication Technology) in agriculture is an emerging field focusing on the agricultural development and rural development in India. Introduction of ICT in Indian agriculture [2] enables the dissemination of requisite information at the right time [6].

The rapid growth of mobile telephony and the introduction of mobile enabled information services provide a means to overcome existing asymmetry of information in all field like agriculture, healthcare and education. There is a big gap between the availability and delivery of agriculture inputs and agriculture infrastructure that can be is bridge by the mobile technologies. A smart phone is the device that is used to make telephone calls, having additional features and abilities like to send and receive e-mail, Wi-Fi and modem ability, internet access, Office documents, easy touch screen operation and most of all the capability to run custom software. The _user interface' is one more important characteristic of smart phone. A smart phone has a touch screen facilities with abilities to zoom in and out using simple interface =buttons, menus and forms and the support of - qwertyll keyboard makes them easy and simple to operate for people who are not very aware with ICT technology and even not enough educated. The software must be easy to operate and farmer has to supply only the specific data required to complete an operation or a process. The cost of the smart phone is varying from law range to high range. So it's easy for farmers to but any kind of smart phone which is in their budget.

\subsection{Android Architecture}

Android is an open source development platform that offers to build the very powerful applications to developers. Android operating system is a stack of software components which is roughly divided into five sections like Applications, Application Framework, Libraries, Android Runtime, Linux Kernel and four main layers. It helps the developers to take free advantage of the device hardware, access location information, run background services, call divert and sms etc. Once the application has been published, it can download from third-party sites or through online stores such as Android Market, the app store run by Google. 
International Journal of Information Sciences and Techniques (IJIST) Vol.6, No.1/2, March 2016

\section{STUDY/ REVIEW OF ANDROID APPLICATIONS FOR AGRICULTURE SECTOR}

The basic information required by the farmers is as follow and shown in the figure 1 . The author shows the information required from the crop planning to the selling of crop. The very basic information need by the farmers are about information of soil, type of seed, required pesticide for the particular crop in all stage of its growth, fertilizer type, crop diseases and its selling. Below are the questions that must be answered for the better production of crop.

- Fundamental information such as which crop to plant? Which seed varieties is to be used?

- When he can show and for weather information is required? Best cultivation practices for my crops and soil

- Which fertilizer and pesticides will be required for the crop?

- The Prices, demand indicators, and logistical information for transport [9].

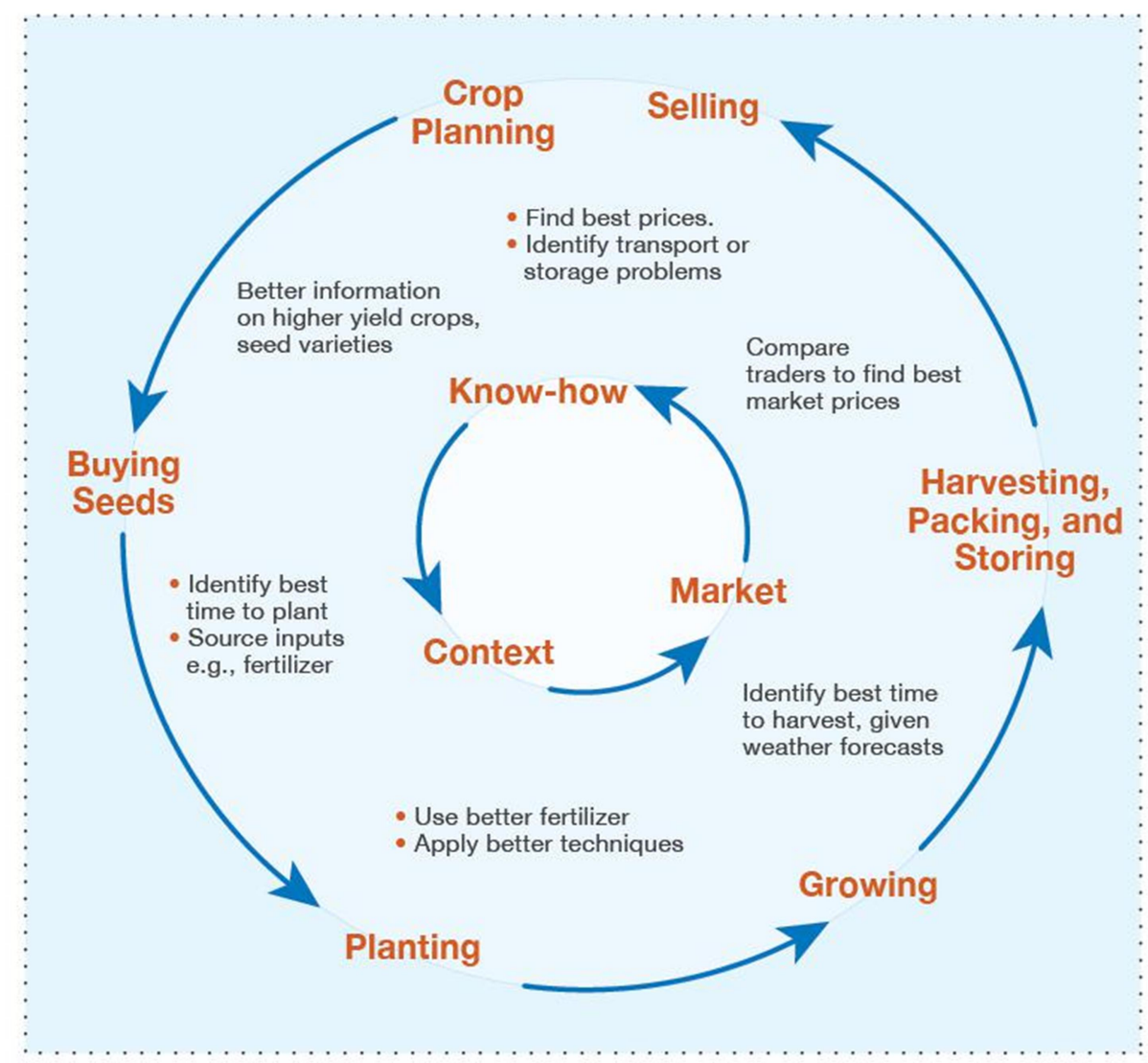

Fig 1 - Information needs of farmers (Adapted from Mittal, 2010)

Agriculture information apps can be categories or classified as follow:

- Business apps

- Conference apps 
International Journal of Information Sciences and Techniques (IJIST) Vol.6, No.1/2, March 2016

- Diseases and pests apps

- Farm management apps

- Learning and reference apps

- Location-based apps

- Market data apps

- Weather apps

In fig. 2, it can be seen the development of apps categories wise in the form of diagram with its percentage (\%). The number of apps developed for the agriculture related activities are very few and it is required to develop one single app through which an uneducated farmers can easily utilise it for the farming activities.

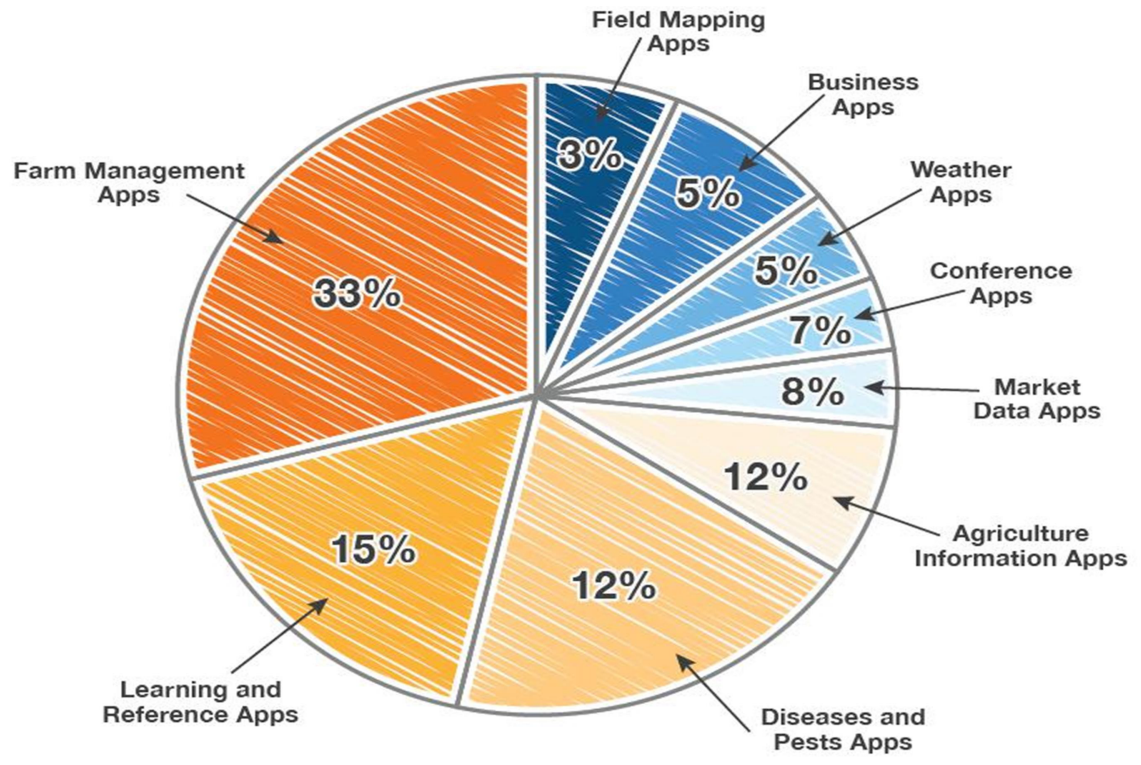

Fig. 2 Development of Android applications (in \%)

We survey the following android app in the different area of agriculture. We found that all apps are having dissimilar features. The FarmManager app is developed for the Greeek farmers for small farm only. The AgroMobile app is useful for only recognition of botanical species and disease detection. The Krishi Ville app is for agricultural commodities, weather forecast updates and agricultural news updates, other farm activities cannot do by this app. The Agriculture Supply Chain Management app is useful for those farmer who want to produce sugarcane. The Scheduling, Controlling And Monitoring of Agricultural Devices app is limited to the work of controlling the motor and pesticides proportion, monitoring the farming activities going on and irrigation. The E-agree app is for detecting the leaf diseases. The Farmer Helping Services provide the Horticulture information about flowers, fruits and vegetables in Gujarati Language. The list of apps with its functionalities and limitations is shown in the table 1. 
International Journal of Information Sciences and Techniques (IJIST) Vol.6, No.1/2, March 2016

Table 1. Android Apps and its description

\begin{tabular}{|c|c|c|}
\hline App Name & Usage & Reference \\
\hline FarmManager & $\begin{array}{l}\text { The management of small farms, designed and } \\
\text { developed to respond to the needs and Characteristics } \\
\text { of farmers of Greek. It can store database, do farm } \\
\text { customization, easy field management, land field } \\
\text { data, easy job recording process, employees and } \\
\text { equipment. }\end{array}$ & {$[2]$} \\
\hline AgroMobile & $\begin{array}{l}\text { Develop Especially for the Indian farmers to assist } \\
\text { them in agricultural needs. It is used for botanical } \\
\text { species recognition and disease detection using a } \\
\text { simple mobile phone with camera. }\end{array}$ & [4] \\
\hline Krishi Ville & $\begin{array}{l}\text { It takes care of the updates of the different } \\
\text { agricultural commodities, weather forecast updates, } \\
\text { agricultural news updates. The application has been } \\
\text { designed taking Indian farming in consideration. }\end{array}$ & [5] \\
\hline $\begin{array}{l}\text { Agriculture Supply Chain } \\
\text { Management }\end{array}$ & $\begin{array}{l}\text { The complete package for farmers who want to do } \\
\text { farming on sugarcane and obtain good production } \\
\text { with proper management. }\end{array}$ & {$[10]$} \\
\hline $\begin{array}{l}\text { Scheduling, Controlling } \\
\text { And Monitoring of } \\
\text { Agricultural Devices }\end{array}$ & $\begin{array}{l}\text { Used to farmer in controlling the motor and } \\
\text { pesticides proportion, monitoring the farming } \\
\text { activities going on in the farm remotely and also } \\
\text { allow for improving the efficiency of the irrigation } \\
\text { process. }\end{array}$ & {$[11]$} \\
\hline E-agree & $\begin{array}{l}\text { Used to detect detects leaf diseases. Also provides } \\
\text { online market place, market rate guide, weather report } \\
\text { and soil information to the farmer. }\end{array}$ & [12] \\
\hline $\begin{array}{l}\text { Agriculture Decision } \\
\text { Support System }\end{array}$ & $\begin{array}{l}\text { Provide information for cultivation of various kinds } \\
\text { of crops in various type of atmosphere. }\end{array}$ & [13] \\
\hline $\begin{array}{l}\text { Solution for farmer } \\
\text { consumer interaction }\end{array}$ & $\begin{array}{l}\text { Provide information to the farmers about how to get } \\
\text { access to better inputs and gain more productivity; get } \\
\text { connected to the end consumers. Also give } \\
\text { information like the activities he should perform right } \\
\text { from the time when the seed germinates till the day } \\
\text { when the crop is ready to be harvested. }\end{array}$ & {$[14]$} \\
\hline
\end{tabular}


International Journal of Information Sciences and Techniques (IJIST) Vol.6, No.1/2, March 2016

\begin{tabular}{|l|l|c|}
\hline MahaFarm & $\begin{array}{l}\text { Helps in their farming activities that include agro- } \\
\text { based crop information, weather updates, daily } \\
\text { market prices and news/loan informational updates. }\end{array}$ & {$[15]$} \\
\hline Farmer Helping Services & $\begin{array}{l}\text { Offers all the Horticulture information about flowers, } \\
\text { fruits and vegetables in Gujarati Language. }\end{array}$ & {$[16]$} \\
\hline Irrigation Control System & $\begin{array}{l}\text { Efficient Use of Water and Power; helps the farmer to } \\
\text { ON/OFF the motor without his physical presence in } \\
\text { the field. }\end{array}$ & {$[17]$} \\
\hline $\begin{array}{l}\text { Kharif and Rabi Crop } \\
\text { Diseases Information }\end{array}$ & $\begin{array}{l}\text { Provides all Kharif and Rabi diseases details } \\
\text { information such as types of diseases, pesticides used, } \\
\text { method for applying pesticides. }\end{array}$ \\
\hline
\end{tabular}

\section{Conclusion}

Different apps are developed and used by farmers for their specific purpose. All this apps have different usage as per its functionalities. Many apps are being utilized for different kind of functionality regarding the farming activities like cropping information, pesticides, fertilizer, seed, selling of crop, irrigation information, estimation of crop production, weather information and information regarding the best practices of farming. We found that many of the apps are static. Instead of that dynamic apps will be better to use. Also if all such listed functionalities are bundle into the one single app and in the native language of the farmer, then it is easy to utilize it.

\section{ACKNOWLEDGEMENTS}

I would like to express my sincerest thanks to the Principal Dr. Atul Patel for his continues support.

\section{REFERENCES}

[1] Steinberger, G., Rothmund, M., \& Auernhammer, H. (2009) -Mobile farm equipment as a data source in an agricultural service architecturel, Computers and Electronics in Agriculture, 65(2), 238246.

[2] Lantzos, T., Koykoyris, G., \& Salampasis, M. (2013) -FarmManager: an Android application for the management of small farmsl, Procedia Technology, 8, 587-592.

[3] Voulodimos, A. S., Patrikakis, C. Z., Sideridis, A. B., Ntafis, V. A., \& Xylouri, E. M. (2010) -A complete farm management system based on animal identification using RFID technologyll, Computers and Electronics in Agriculture, 70(2), 380-388.

[4] Prasad, S., Peddoju, S. K., \& Ghosh, D. (2013) -AgroMobile: A Cloud-Based Framework for Agriculturists on Mobile Platformll, International Journal of Advanced Science and Technology, 59, 41-52.

[5] Singhal, M., Verma, K., \& Shukla, A. (2011, December) - Krishi Ville-Android based solution for Indian agriculturell, In Advanced Networks and Telecommunication Systems (ANTS), 2011 IEEE 5th International Conference on (pp. 1-5). IEEE.

[6] ICTinIndianAgriculture-DisseminatingInformationtoFarmers, $\mathrm{http} / / /$ www.iupindia.in/205/EE_ICT in Indian_Agriculture 44.html

[7] KISSAN KERALA, http://www.kissankerala.net/mobile/index.jsp\#mobile 
International Journal of Information Sciences and Techniques (IJIST) Vol.6, No.1/2, March 2016

[8] http://blog.floatlearning.com/Portals/241955/docs/float\%20mobile\%20learning\%20-

$\% 20$ the $\% 20$ application $\% 20$ of $\% 20$ mobile $\% 20$ computing $\% 20$ to $\% 20$ the $\% 20$ business $\% 20$ of $\% 20$ farmin g.pdf

[9] Mittal, S., Gandhi, S., \& Tripathi, G. (2010) - Socio-economic impact of mobile phones on Indian agriculturell, New Delhi: Indian Council for Research on International Economic Relations, (p. 53).

[10] Monika Chirmade, Komal Tayade, Gaurav Sham Bankar, Shounak Sugave (2015) - Agriculture Supply Chain Management Based Android Applicationll, International Journal of Advanced Research in Computer and Communication Engineering, Vol. 4, Issue 4

[11] Mukesh Choudhary, Sumeet Dhone, Akshay Jadhav, Chetan Dhandal, Prof. J. M. Nighot (2015) - Scheduling, Controlling And Monitoring of Agricultural Devices Using Android Applicationll, International Journal of Advanced Research in Computer Engineering \& Technology, Vol. 4, Issue 4

[12] Santosh Reddy, Abhijeet Pawar, Sumit Rasane, Suraj Kadam (2015) -A Survey on Crop Disease Detection and Prevention using Android Applicationll, International Journal of Innovative Science, Engineering \& Technology, Vol. 2, Issue 4

[13] Rachana P. Koli1, V. D. Jadhav2 (2015), - Agriculture Decision Support System As Android Applicationll, International Journal of Science and Research, Vol. 4 Issue 4

[14] Deshpande Radhika, Bhalekar Dipali, Mutkule Prasad, Sanjay Pandhare, Nawale Akshay(2015) -One Stop Solution for Farmer Consumer Interactionll, IJCA Proceedings on National Conference on Advances in Computing NCAC (6):16-19

[15] Aniket Bhave, Rahul Joshi, Ryan Fernandes(2014) - MahaFarm - An Adroid Based Solution for Remunerative Agriculturell, International Journal of Research in Advent Technology, Vol.2, No.4

[16] Patel, V. B., Thakkar, R. G., \& Radadiya, B. L. (2014) ॥ An Android Application for Farmers to Disseminate Horticulture Informationll, International Journal of Computer Applications, 88(4)

[17] Laxmi Shabadi, Nandini Patil, Nikita. M, Shruti. J, Smitha. P \& Swati. C (2014) \| Irrigation Control System Using Android and GSM for Efficient Use of Water and Powerll, International Journal of Advanced Research in Computer Science and Software Engineering, Volume 4, Issue 7

[18] Mr.Vimal B.Patel, Dr. Rahul G. Thakkar, Mr. Hardikkumar V. Desai (2014) \|An Android Application for Farmers for Kharif and Rabi Crop Diseases Informationll, International Journal of Advanced Research in Computer Science and Software Engineering, Volume 4, Issue 10

\section{AuTHORS}

Hetal Patel has completed her Bachelor of Computer Science from Sardar Patel University in 2004. In 2006, she holds degree of Master of Computer Applications from Sardar Patel University in 2006. Since 2014, she is presently working with Smt. Chandaben Mohanbhai Patel Institute of Computer Applications, under CHARUSAT University of Science and Technology, situated at Changa, Gujarat, as an Assistant Professor. She is pursuing Ph.D. in the subject of Data Mining.

Dr. Dharmendra Patel received Bachelor Degree in Industrial Chemistry- BSc. (Industrial Chemistry) from North Gujarat University, Gujarat, India and Master Degree in Computer Applications (MCA) from North Gujarat University, Gujarat, India. He completed his Ph.D., in the field of Web Usage Mining. He is HOD of MCA Department at Smt. Chandaben Mohanbhai Patel Institute of Computer Applications, under CHARUSAT University of Science and Technology (CHARUSAT), Changa, Gujarat, India.
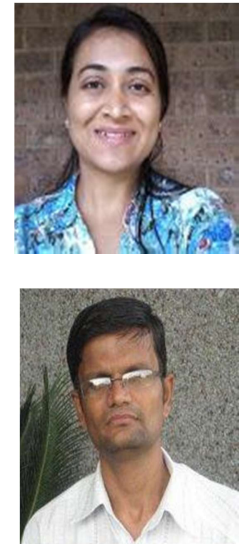